\title{
Correlates of HIV knowledge and sexual risk behaviors among female military personnel
}

\author{
Ekere Essien ${ }^{1 *}$, Osaro Mgbere ${ }^{1,2}$, Ernest Ekong ${ }^{1,3}$, Susan Abughosh ${ }^{1}$, Emmanuel Monjok ${ }^{1}$ \\ From $16^{\text {th }}$ International Symposium on HIV and Emerging Infectious Diseases \\ Marseille, France. 24-26 March 2010
}

\section{Background}

Uniformed services personnel are at an increased risk of HIV infection. We examined the HIV/AIDS knowledge and sexual risk behaviors among female military personnel to determine the correlates of HIV risk behaviors in this population.

\section{Methods}

The study used a cross-sectional design to examine HIV/AIDS knowledge and sexual risk behaviors in a sample of 346 females drawn from two military cantonments in Southwestern Nigeria. Data was collected between 2006 and 2007. Using bivariate analysis and multivariate logistic regression, HIV/AIDS knowledge and sexual behaviors were described in relation to socio-demographic characteristics of the participants.

\section{Results}

Multivariate logistic regression analysis revealed that level of education and knowing someone with HIV/ AIDS were significant $[\mathrm{p}<0.05]$ predictors of HIV knowledge in this sample. Condom use self-efficacy was significantly $[\mathrm{p}<0.05]$ predicted by annual income and ethnicity. Condom use attitudes were also significantly [ $<0.05$ ] associated with number of children, annual income, and number of sexual partners.

\section{Discussion}

Data indicates the importance of incorporating these predictor variables into intervention designs.

\section{Author details}

${ }^{1}$ University of Houston, Houston, USA. ${ }^{2}$ Houston Department of Health and Human Services, Houston, USA. ${ }^{3}$ Institute for Health Research and Development, Lagos, Nigeria.

Published: 11 May 2010

doi:10.1186/1742-4690-7-S1-P120

Cite this article as: Essien et al:: Correlates of HIV knowledge and sexual risk behaviors among female military personnel. Retrovirology 2010 7(Suppl 1):P120.
Submit your next manuscript to BioMed Central and take full advantage of:

- Convenient online submission

- Thorough peer review

- No space constraints or color figure charges

- Immediate publication on acceptance

- Inclusion in PubMed, CAS, Scopus and Google Scholar

- Research which is freely available for redistribution 